九州大学学術情報リポジトリ

Kyushu University Institutional Repository

\title{
Occurrence of Weed Species in Pear Orchards in Chungnam Province of Korea
}

\section{Jia, WeiQiang}

Department of Bioproduction Environmental Sciences, Faculty of Agriculture, Kyushu University | Department of Crop Science, Chungnam National University

\section{Hwang, Ki Seon}

Department of Bioproduction Environmental Sciences, Faculty of Agriculture, Kyushu University | Department of Crop Science, Chungnam National University

Won, Ok Jae

Department of Bioproduction Environmental Sciences, Faculty of Agriculture, Kyushu University | Department of Crop Science, Chungnam National University

\section{Oh, Taek-Keun}

Department of Bioproduction Environmental Sciences, Faculty of Agriculture, Kyushu University | Department of Bio-Environmental Chemistry, Chungnam National University

他

https://doi.org/10.5109/1799305

出版情報：九州大学大学院農学研究院紀要. 62 (1)，pp.75-80，2017-02-24. Faculty of Agriculture， Kyushu University

バージョン :

権利関係 : 


\title{
Occurrence of Weed Species in Pear Orchards in Chungnam Province of Korea
}

\author{
WeiQiang JIA ${ }^{1, \dagger}$, Ki Seon HWANG ${ }^{1, \dagger}$, Ok Jae WON ${ }^{1}$, Taek-Keun $\mathrm{OH}^{2, *}$, \\ Yoshiyuki SHINOGI ${ }^{3}$ and Kee Woong PARK ${ }^{1, *}$
}

\author{
Department of Bioproduction Environmental Sciences, Faculty of Agriculture, Kyushu University, \\ Hakozaki 6-10-1 Higashi-Ku, Fukuoka City 812-8581, Japan \\ (Received October 28, 2016 and accepted November 4, 2016)
}

\begin{abstract}
A survey of weed occurrence was conducted to identify noxious weed species in pear orchards to obtain basic information for effective weed control. The survey was conducted in pear orchards situated in Chungnam province of Korea from April to June 2015, for spring, and from September to October 2015, for autumn. A total of 19 survey sites were randomly selected. The weed species were summarized as a total of 63 taxa belonging to 24 families. Specifically, 18 exotic weeds, belonging to 9 families, were identified. The majority of weeds were Compositae (10), followed by Poaceae (7) and Polygonaceae (6). Rumex crispus and Poa annua were dominant weeds. In terms of life cycle, there were 17 species of annual weeds, 13 species of biennial weeds, and 17 species of perennial weeds for the spring survey, and 15 species of annual weeds, 6 species of biennial weeds, and 11 species of perennial weeds for the autumn survey. The continuous application of single control method was unbeneficial for weed management in pear orchards. These results could be useful for the establishment of weed multi-control methods in pear orchards in Chungnam province of Korea.
\end{abstract}

Key words: Dominant weed, exotic weed, orchard field, weed flora, weed occurrence

\section{INTRODUCTION}

In Korea, the cultivated area of fruit trees increased from 20,000 ha in 1955 to 155,000 ha in 2005 , of which pear trees occupied a significant portion (Ha and Chung, 2012). Moreover, the pear tree area in Chungnam province is ranked third in the country, encompassing 1,280 ha and concentrated in Cheonan city (Yoon, 2014). With this increasing cultivated area, a large amount of labor is required. However, the rapid ageing of the population and labor shortages are serious problems in Korea, which leads to the decline of productivity (Kim, 2009). The use of herbicides is one of the most effective ways to improve productivity.

In pear orchards, there is a competitive relationship for water and nutrients between weeds and pear trees. Weeds have a significant influence on pear tree vitality (i.e., shoot extension, leaf size, and fruit size) (Larsen and Ries, 1960; Raese, 1991). Additionally, weeds also serve as an inoculum source for diseases and alternate host for insects (Johnson et al., 1993; Fitzgerald and Solomon, 2004). The application of herbicide to establish weedfree pear orchards can help avoid these threats. However, the excessive and indiscriminate application of

\footnotetext{
${ }^{1}$ Department of Crop Science, Chungnam National University, Daejeon 34134, Korea

${ }^{2}$ Department of Bio-Environmental Chemistry, Chungnam National University, Daejeon 34134, Korea

${ }^{3}$ Department of Bioproduction Environmental Sciences, Faculty of Agriculture, Kyushu University, Hakozaki 6-10-1, HigashiKu, Fukuoka City 812-8581, Japan

$\uparrow$ These two authors contributed equally to this work and should be considered co-first authors

* Corresponding author (E-mail: ok5382@cnu.ac.kr) (T.K. Oh)

* Corresponding author (E-mail: parkkw@cnu.ac.kr) (K.W. Park)
}

herbicides brings about a series of adverse effects (e.g., water or soil pollution and increase of herbicide resistant weeds) (Zhang et al., 2005; Park et al., 2014). Consequently, it is necessary to investigate the weed species present and to select effective herbicide or management methods accordingly.

Studies of the occurrence of weeds show their abundance and diversity in orchards. Hwang and Park (2016) reported that 64 weed species belonging to 27 families, including 39 annuals and 25 perennials, were identified in apple orchards of Chungnam province. Furthermore, according to another classification, 7 species of grasses, 60 species of broad leaves, and 2 species of sedges were observed in pear orchards (Jung et al., 1997). In addition, a number of exotic weeds were also identified in orchards; for example, Chenopodium album var. album (Chenopodiaceae) and Conyza Canadensis (Compositae) had a relatively high occurrence frequency (Oh et al., 2004). Due to the diversity of weeds, it is more effective to use integrated weed management methods than any single weed management method (Rifai et al., 2002).

The objective of the current study is to determine pear orchard weed flora and corresponding weed management methods, as well as to provide a useful database to identify troublesome weed species and control technologies. On that ground, understanding the occurrence of weeds is crucial for effective weed control in pear orchards. The ultimate purpose of performing this weed survey is to obtain maximum pear yields while reducing labor force input through reasonable and effective weed management methods in the province of Chungnam. 


\section{MATERIALS AND METHODS}

\section{Survey period and sites}

The study was carried out in the Chungnam region, (i.e., Daejeon, and Sejong) from April to June 2015, for spring, and from September to October 2015, for autumn. The 19 survey sites were randomly selected in pear orchards. All of the survey sites were taking little to no preventive measures against weeds.

\section{Survey methods}

The frequency, species, and number of weeds were investigated at each survey site. GPS (ICE CPS 100c) information and address of survey sites were recorded to ensure precise test field location. As a result, exotic weed species locations could be known in each pear orchard. The area of each test field was estimated by pacing; counting the number of steps of a researcher from one end of the field to the other. Weed population and surrounding areas were recorded by photography with a camera (Canon 100D) in the test fields (Hwang et al., 2014).

Weed species were identified by visual observation in the survey field. The covering ratio was computed according to Braun-Blanquet (7-level system, 5, 4, 3, 2, $1,+$ and r) (1964). Braun-Blanquet's coverage scale for weed estimation was as follows: 5 , covering more than $75 \%$ of the whole test field; 4 , any number of individuals covering $50-75 \%$ of the area; 3 , any number of individuals covering $25-50 \%$ of the area; 2 , very numerous or covering at least $5 \%$ of the area; 1 , plentiful but of small cover value; + , sparsely present, cover small; $r$, very sparsely present, cover very small (Poore, 1955).

\section{Data analysis}

The results of weed survey were compiled into lists according to the Synonymic List of Vascular Plants of Korea (Korea National Arboretum, 2007). Exotic weeds (EW) were identified by "Colored Illustrations of Naturalized Plants of Korea" (Park, 2009) and with the paper describing upland field flora by Lee et al., in 2015. For classification into life cycles, weeds were divided into annuals, biennials, and perennials (Raunkiaer, 1934). Distribution proportion of each family of weeds was then calculated.

The importance values were analyzed based on spring and autumn survey results (Curtis and McIntosh, 1950). Frequency was defined as a percentage of weed samples where some species are present in all the orchard fields under observation. The frequency formula is the number of samples of any species multiplied by the total number of samples of all species divided by 100 . Relative frequency (RF) was calculated by dividing frequency by the sum of frequencies of all the species multiplied by 100 . The relative coverage (RC) is the coverage of any species divided by the percentage of total coverage of all the species. The importance value (IV) is the importance index for assessing biodiversity, which is calculated by adding the relative frequency and the relative coverage and dividing the result in half.

\section{RESULTS AND DISCUSSION}

According to the results of two survey seasons, there were a total of 63 taxa including 24 families, 47 genera, 57 species, and 6 varieties. The majority of weed species belonged to the Compositae (10), followed by the Poaceae (7) and Polygonaceae (6). For the spring survey, weeds were summarized as 47 taxa belonging to 20 families, 35 genera, 41 species, and 6 varieties. The families were mainly classified as Poaceae, Compositae, and Polygonaceae in order of importance. Rumex crispus (7.45\%) was the most dominant species, followed by Poa annua (7.98\%) and Stellaria aquatic (7.98\%) (Table 1). In the autumn survey, the weeds were summarized as 32 species belonging to 18 families and 31 genera. Compositae and Polygonaceae were identified as the main families. The most dominant weed species was Rumex crispus (9.47\%) followed by Poa annua (7.27\%) and Stellaria aquatic (6.17\%) (Table 2). Based on two seasons' data, Rumex crispus and Poa annua were the dominant weed species in pear orchards. The two seasons' results were similar to apple orchard weed species surveys of the Chungnam region in 2015 (Hwang and Park, 2016). This is because the two studies were carried-out in similar survey periods and regions, which leads to similarities in weed types.

In addition, 12 exotic weeds were identified in the spring survey, including Rumex crispus (7.45\%), Trifolium repens (3.61\%) and Veronica didyma var. lilacina (3.31\%) etc. (Table 1). Meanwhile, in the autumn survey, 10 exotic weeds were discovered in pear orchards, including Rumex crispus (9.47\%), Taraxacum officinale (5.02\%), and Eclipta alba (4.49\%) etc. (Table 2$)$. In terms of results combining two seasons' surveys, the Rumex crispus was confirmed as the most dominant exotic weed. A similar previous study (2003) conducted for the occurrence of exotic weeds in orchards of Chungnam region showed that Amaranthus lividus was the most dominant exotic weed (Choi et al., 2009). This difference in the exotic weed dominance between 2003 and 2015 indicates that it is necessary to survey weed occurrence regularly.

The analysis of weed life-cycles showed that there were 17 annual weeds, 13 biennial weeds, and 17 perennial weeds in the spring survey. For all weed species, the annuals occupied $36.17 \%$, biennials $27.66 \%$, and perennials $36.17 \%$ in the spring survey (Fig. 1.A). According to importance values ranking, the top 10 weed species were classified as $50 \%$ of perennials, $30 \%$ of biennials, and $20 \%$ of annuals. Top 10 weed species data showed that the most dominant weeds were perennial in the spring. In the autumn survey, there were annual weeds (15), biennial weeds (6), and perennial weeds (11). Moreover, the annual weeds occupied $46.88 \%$ of all weed species and $50 \%$ of the top 10 weed species (Fig. 1. B). The autumn results were similar to those from the 2003 survey of apple orchards (Park et al., 2005) in that a large number of annual weeds were observed in orchards.

According to the dominance value analysis accord- 
Table 1. Occurrence of weed species in spring pear orchards in Chungnam in 2015

\begin{tabular}{|c|c|c|c|c|c|}
\hline Rank & Scientific name & Family & Life cycle & I.V. & EW \\
\hline 1 & Rumex crispus & Polygonaceae & Perennial & 7.45 & 0 \\
\hline 2 & Poa annua & Poaceae & Annual & 7.27 & \\
\hline 3 & Stellaria aquatica & Caryophyllaceae & Biennial & 6.17 & \\
\hline 4 & Plantago asiatica & Plantaginaceae & Perennial & 5.46 & \\
\hline 5 & Artemisia princeps & Compositae & Perennial & 4.66 & \\
\hline 6 & Stellaria media & Caryophyllaceae & Biennial & 4.18 & \\
\hline 7 & Rorippa indica & Cruciferae & Perennial & 3.91 & \\
\hline 8 & Trifolium repens & Leguminosae & Perennial & 3.61 & 0 \\
\hline 9 & Capsella bursa-pastoris & Cruciferae & Biennial & 3.57 & \\
\hline 10 & Veronica didyma var. lilacina & Scrophulariaceae & Annual & 3.31 & $\bigcirc$ \\
\hline 11 & Agropyron tsukushiense & Poaceae & Annual & 3.09 & \\
\hline 12 & Galium spurium var. echinospermon & Rubiaceae & Biennial & 2.74 & \\
\hline 13 & Taraxacum officinale & Compositae & Perennial & 2.74 & 0 \\
\hline 14 & Humulus japonicus & Cannabaceae & Annual & 2.63 & \\
\hline 15 & Chenopodium ficifolium & Chenopodiaceae & Annual & 2.22 & $\bigcirc$ \\
\hline 16 & Acalypha australis & Euphorbiaceae & Annual & 2.10 & \\
\hline 17 & Poa sphondylodes & Poaceae & Perennial & 2.03 & \\
\hline 18 & Persicaria vulgaris & Polygonaceae & Annual & 2.03 & \\
\hline 19 & Polygonum aviculare & Polygonaceae & Annual & 2.03 & \\
\hline 20 & Oenanthe javanica & Umbelliferae & Perennial & 2.03 & \\
\hline 21 & Chenopodium album var. centrorubrum & Chenopodiaceae & Annual & 1.92 & 0 \\
\hline 22 & Commelina communis & Commelinaceae & Annual & 1.81 & \\
\hline 23 & Duchesnea indica & Rosaceae & Perennial & 1.81 & \\
\hline 24 & Echinochloa utilis & Poaceae & Annual & 1.69 & \\
\hline 25 & Persicaria hydropiper & Polygonaceae & Annual & 1.69 & \\
\hline 26 & Calystegia sepium var. japonicum & Convolvulaceae & Perennial & 1.58 & \\
\hline 27 & Veronica persica & Scrophulariaceae & Biennial & 1.46 & $\bigcirc$ \\
\hline 28 & Digitaria ciliaris & Poaceae & Annual & 1.17 & \\
\hline 29 & Cerastium glomeratum & Caryophyllaceae & Biennial & 1.05 & $\bigcirc$ \\
\hline 30 & Chenopodium album & Chenopodiaceae & Annual & 1.05 & O \\
\hline 31 & Rorippa palustris & Cruciferae & Perennial & 1.05 & \\
\hline 32 & Agropyron tsukushiense var. transiens & Poaceae & Perennial & 1.05 & \\
\hline 33 & Alopecurus aequalis & Poaceae & Annual & 1.05 & \\
\hline 34 & Taraxacum platycarpum & Compositae & Perennial & 0.82 & \\
\hline 35 & Rubia akane & Rubiaceae & Perennial & 0.75 & \\
\hline 36 & Sonchus oleraceus & Compositae & Biennial & 0.64 & $\bigcirc$ \\
\hline 37 & Leonurus japonicus & Labiatae & Biennial & 0.64 & \\
\hline 38 & Persicaria senticosa & Polygonaceae & Annual & 0.64 & \\
\hline 39 & Potentilla freyniana & Rosaceae & Perennial & 0.64 & \\
\hline 40 & Solanum carolinense & Solanaceae & Perennial & 0.64 & \\
\hline 41 & Solanum nigrum & Solanaceae & Annual & 0.64 & \\
\hline 42 & Achyranthes fauriei & Amaranthaceae & Perennial & 0.53 & \\
\hline 43 & Senecio vulgaris & Compositae & Biennial & 0.53 & O \\
\hline 44 & Cardamine flexuosa & Cruciferae & Biennial & 0.53 & \\
\hline 45 & Cardamine fallax & Cruciferae & Biennial & 0.53 & \\
\hline 46 & Conyza canadensis & Compositae & Biennial & 0.41 & 0 \\
\hline 47 & Malva sylvestris var. mauritiana & Malvaceae & Biennial & 0.41 & \\
\hline
\end{tabular}

I.V.: importance value.

EW: exotic weed. 
Table 2. Occurrence of weed species in autumn pear orchards in Chungnam in 2015

\begin{tabular}{|c|c|c|c|c|c|}
\hline Rank & Scientific name & Family & Life cycle & I.V. & $\mathrm{EW}$ \\
\hline 1 & Rumex crispus & Polygonaceae & Perennial & 9.47 & $\bigcirc$ \\
\hline 2 & Poa annua & Poaceae & Annual & 7.98 & \\
\hline 3 & Stellaria media & Caryophyllaceae & Biennial & 7.98 & \\
\hline 4 & Digitaria ciliaris & Poaceae & Annual & 7.51 & \\
\hline 5 & Commelina communis & Commelinaceae & Annual & 7.35 & \\
\hline 6 & Rorippa indica & Cruciferae & Perennial & 5.86 & \\
\hline 7 & Taraxacum officinale & Compositae & Perennial & 5.02 & $\bigcirc$ \\
\hline 8 & Eclipta alba & Compositae & Annual & 4.49 & $\bigcirc$ \\
\hline 9 & Metaplexis japonica & Asclepiadaceae & Perennial & 4.18 & \\
\hline 10 & Galium spurium & Rubiaceae & Annual & 4.18 & \\
\hline 11 & Oenanthe javanica & Umbelliferae & Perennial & 3.81 & \\
\hline 12 & Calystegia sepium & Convolvulaceae & Perennial & 2.85 & \\
\hline 13 & Sonchus oleraceus & Compositae & Biennial & 2.85 & $\bigcirc$ \\
\hline 14 & Acalypha australis & Euphorbiaceae & Annual & 2.85 & \\
\hline 15 & Phytolacca americana & Phytolaccaceae & Perennial & 2.38 & $\bigcirc$ \\
\hline 16 & Potentilla freyniana & Rosaceae & Perennial & 2.33 & \\
\hline 17 & Cyperus amuricus & Cyperaceae & Annual & 2.01 & \\
\hline 18 & Solanum carolinense & Solanaceae & Perennial & 1.85 & $\bigcirc$ \\
\hline 19 & Senecio vulgaris & Compositae & Biennial & 1.69 & $\bigcirc$ \\
\hline 20 & Persicaria thunbergii & Polygonaceae & Annual & 1.16 & \\
\hline 21 & Bidens bipinnata & Compositae & Annual & 1.16 & \\
\hline 22 & Persicaria senticosa & Polygonaceae & Annual & 1.16 & \\
\hline 23 & Lindernia procumbens & Scrophulariaceae & Annual & 1.16 & \\
\hline 24 & Pilea mongolica & Urticaceae & Annual & 1.16 & \\
\hline 25 & Duchesnea indica & Rosaceae & Perennial & 1.00 & \\
\hline 26 & Erigeron annuus & Compositae & Biennial & 1.00 & $\bigcirc$ \\
\hline 27 & Cuscuta pentagona & Convolvulaceae & Annual & 1.00 & $\bigcirc$ \\
\hline 28 & Polygonum aviculare & Polygonaceae & Annual & 1.00 & \\
\hline 29 & Veronica didyma & Scrophulariaceae & Biennial & 1.00 & \\
\hline 30 & Crepidiastrum sonchifolium & Compositae & Biennial & 0.84 & \\
\hline 31 & Oxalis corniculata & Oxalidaceae & Perennial & 0.84 & \\
\hline 32 & Pharbitis nil & Convolvulaceae & Annual & 0.84 & $\bigcirc$ \\
\hline
\end{tabular}

I.V.: importance value.

EW: exotic weed

ing to Braun-Blanquet's scale, the covering ratio initially increased, and then decreased in the two seasons surveyed (Fig. 2). In the spring survey, the dominance value was level + and 1 (both of 33.93\%) in pear orchards. In the autumn survey, $44.94 \%$ of pear orchards had dominance values of 1 . These results indicated that weed occurrence frequency was low in pear orchards.

The study defined the most dominant weed species was Rumex crispus, which is an exotic weed that belongs to the Polygonaceae family, in pear orchards of the Chungnam region. Meanwhile, the main noxious weeds were perennial in the spring and annual in autumn. At present, mowing can be used to control the rhizome of Rumex crispus in both spring and autumn. In addi- tion, mulching can also reduce weed occurrence to a certain extent. However, mulching is inconvenient for fertilization treatments and increases production costs. Likewise, sod-culture can partly control Poa annua and Stellaria aquatica through the rapid growth of white clover (Trifolium repens) coverage of pear orchards in spring, and Poa annua and Stellaria media through the cold resistance of hairy vetch (Vicia villosa Roth) and its coverage of pear orchards in autumn. However, the effect of a single control method is unsatisfactory in orchards (Rifai et al., 2002). Thus, periodical surveys to identify weed types can be beneficial to the application of targeted, more effective, multi-control methods for preventing weed occurrence. 


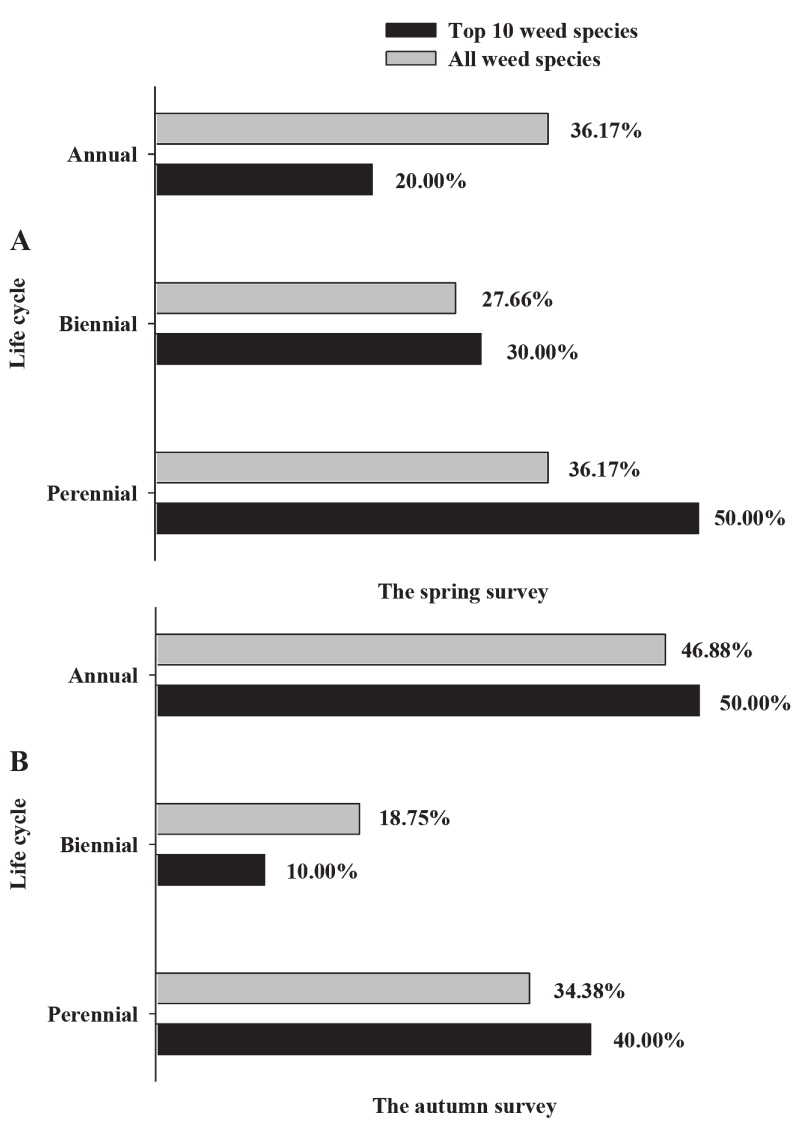

Fig. 1. Classification of all weed species and top 10 weed species occurring in pear orchards fields based on life cycle according to A) spring and B) autumn survey.

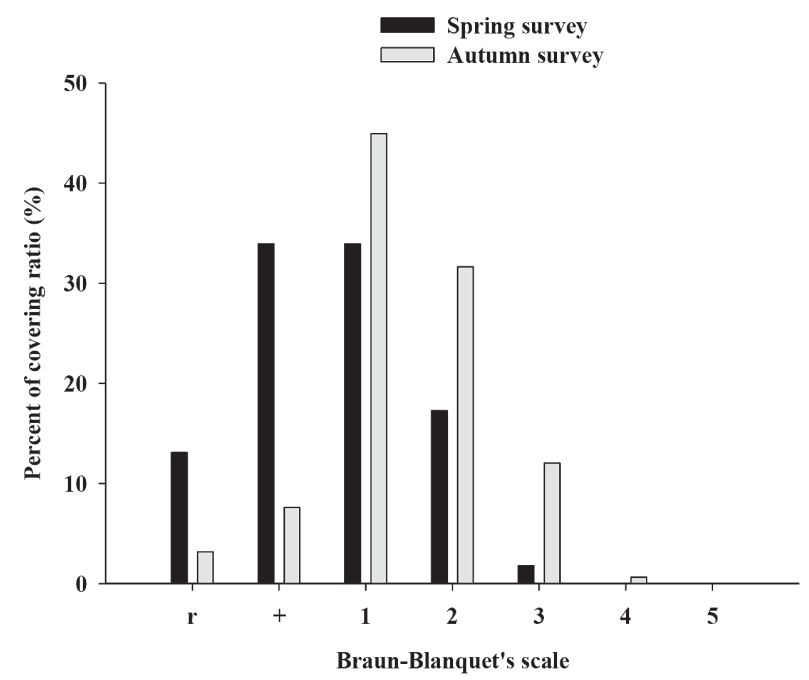

Fig. 2. Percent of covering ratio by Braun-Blanquet's cover-abundance scale (from $\mathrm{r}$ to 5 ) at total survey sites in spring and autumn of 2015. (Braun-Blanquet's scale: "r", cover very small; "+", cover small; "1", plentiful but of small cover value; "2", cover at least 5\%; "3", cover 25-50\%; "4", cover $50-75 \%$; "5", cover more than $75 \%$ of the area.).

\section{ACKNOWLEDGMENT}

This work was carried out with the support of "Cooperative Research Program for Agriculture Science \& Technology Development (Project No. PJ011307012017)" Rural Development Administration, Republic of Korea.

\section{REFERENCES}

Braun-Blanquet J. 1964 Pflanzensoziologie, Grundzüge der Vegetationskunde, $3^{\text {rd }}$ ed. Springer-Verlag Press, Berlin

Choi B., D. Song, J. Roh, Y. Ku, and C. Lee 2009 Monitoring of exotic weeds on upland fields of Chungcheong region in Korea. Korean J. Weed Sci, 29: 150-158

Curtis J. T. and R. P. McIntosh 1950 The interrelations of certain analytic and synthetic phytosociological characters. Ecology, 31: $434-455$

Fitzgerald J. D. and M. G. Solomon 2004 Can flowering plants enhance numbers of beneficial arthropods in UK apple and pear orchards. Biocontrol Sci. Techn., 14: 291-300

Ha S. and D. Chung 2012 Agricultural Status and Soils in Korea. Korean J. Soil Sci. \& Fert., 45: 118-126

Hwang K. S. and K. W. Park 2016 A Survey of Weed Occurrence and Management on Apple Orchard Fields in Chungnam Province in Korea. Weed Turf. Sci., 5: 5-9

Hwang K. S., M. Y. Eom, S. H. Park, O. J. Won, S. J. Suh, I. Y. Lee and K. W. Park 2014 Occurrence and distribution characteristics of weed species on upland Chinese cabbage fields in Chungnam province. CNU J. Agric. Sci., 41: 303-308

Johnson K. B., V. O. Stockwell, R. J. McLaughlin, D. Sugar, J. E. Loper and R. G. Roberts 1993 Effect of antagonistic bacteria on establishment of honey bee-dispersed Erwinia amylovora in pear blossoms and on fire blight control. PhytopathologyNew York and Baltimore then stpaul, 83: 995

Jung J. S., J. S. Lee and C. D. Choi 1997 Weed occurrence in apple orchard in Korea. Korean J. Weed Sci., 17: 147-156

Kim A. E 2009 Global migration and South Korea: foreign workers, foreign brides and the making of a multicultural society Ethnic. Racial. Stud., 32: 70-92

Korea National Arboretum (KNA) 2007 A synonymic list of vascular plants in Korea. Korea National Arboretum Press, Pocheon

Larsen R. P. and S. K. Ries 1960 Simazine for controlling weeds in fruit tree and grape plantings. Weeds, 8: 671-677

Lee I. Y., Y. J. Oh, S. H. Hong, J. K. Choi, S. J. Heo, C. Y. Lee, K. S. Hwang, K. W. Park, S. H. Cho, O. D. Kwon, I. B. Im, S. K. Kim, D. G. Seong, Y. J. Chung, C. S. Kim, J. Lee, H. A. Seo and H. M. Jang 2015 Weed Flora Diversity and Composition on Upland Field of Korea. Weed Turf. Sci., 4: 159-175

Oh S., B. Moon, C. Kim and I. Lee 2004 Distribution of exotic weeds in agricultural fields of the Gyeonggi, Gangwon and Jeju areas in Korea. Korean J. Weed Sci., 24: 138-148

Park J. E., I. Y. Lee, S. M. Oh, T. S. Park, C. S. Kim, B. C. Moon, J R. Cho, S. T. Lim, I. B. Im, J. G. Kang, S. Kim, J. B. Hwang, S. B. Song, S. H. Ji, D. S. Kang and K. R. Chung 2005 Characteristics of weed flora and weed community on orchard field in the Korea. Korean J. Weed Sci., 25: 267-274

Park S. H 2009 New illustrations and photographs of naturalized plants of Korea. Ilchokak Press Inc., Seoul, p. 575

Park T. S., K. Y. Seong, H. S. Cho, M. C. Seo, H. W. Kang and K. W. Park 2014 Current status, mechanism and control of herbicide resistant weeds in rice fields of Korea. CNU J. Agric. Sci., 41: 85-99

Poore M. E. D 1955 The use of phytosociological methods in ecological investigations: I. The Braun-Blanquet System. J. Ecol., 43: $226-244$

Raese J. T 1991 Importance of weed control and nitrogen fertilizer on growth and yield of young bearing apple and pear trees. J. Sustain Agric., 1: 7-18 
Raunkiaer C. 1934 Plant life forms. The Clarendon Press, Oxford

Rifai M. N., T. Astatkie, M. Lacko-Bartosova and J. Gadus 2002 Effect of two different thermal units and three types of mulch on weeds in apple orchards. J. Environ. Eng. Sci., 1: 331-338 Yoon S. T 2014 Technology for processing and quality improve- ment of Cheonan pear for revitalization in the market. Research Report. Dankook Univ. Press, Yongin, Korea

Zhang H. J., X. Liu and B. G. Gu 2005 The identification and management of herbicide resistance weeds. Pestic. Sci. Admi., 26: $27-33$ 